\title{
COMPENSATION FOR NON-UNIFORMITY IN A MESHED ELECTRICAL NETWORK
}

\author{
J. Survilo \\ Riga Technical University, \\ 1 Kronvalda Blvd., LV-1010, Riga, LATVIA
}

\begin{abstract}
Non-uniform electrical networks (meshed included), providing more reliable supply of electric energy to consumers, have greater losses than uniform ones. To upgrade such a network by reducing losses, special measures are provided, which should be done at the least cost. An effective measure of the kind would be introduction of opposing voltage or complementary reactances in some branches of the network. In this case, to determine the required parameters, a non-uniform meshed network should be disintegrated into separate cells - closed loops with equivalent node loads, which are the sum of node loads and the flows not belonging to a given cell. Then the circulating power of all cells is calculated, and the cell with the maximum circulating power is selected to be upgraded. For this purpose, in this cell the pre-defined opposing voltage or complementary reactance is brought. If the total power loss in the network after the first step of upgrading is not satisfactory, a next similar step should be taken, and a next cell singled out for upgrading. Such cell upgrading should be continued until the total losses stop decreasing.
\end{abstract}

Key words: closed loop, meshed electrical systems, non-uniform networks, power losses, quadrature booster transformer.

\section{INTRODUCTION}

Meshed networks are known to provide reliable supply of electrical energy to consumers [1,2]. In such networks high- and medium-voltage rated values are used. For individual consumers also low-voltage meshed networks exist. They can be built up of power lines with diverse relationships between the direct sequence reactance of a power line and the active resistance of the phase conductor of this line. This especially relates to the networks consisting of overhead and cable lines or to meshed networks comprising two voltage ratings, which requires that here be power transformers [3]. In such non-uniform systems the active power losses are higher than in uniform ones. It is possible to reduce these losses by transforming a non-uniform network into a uniform one. However, it is an expensive measure, which requires adjustment of parameters for almost all the network branches. In closed loops of a non-uniform network the circulating currents arise which are responsible for the growth in energy losses as compared with a similar uniform network. In an isolated non-uniform loop with a number of loads the additional losses are proportional to the squared circulating current, which is calculated out of all loads and branch parameters of the loop. To cope with additional losses of such a loop it is enough to eliminate the circulating current. As concerns meshed nonuniform systems, the task appears to be more complicated. First, the circulating current in a non-isolated loop (cell) of a meshed system cannot be determined by a 
routine procedure as it is in the case of an isolated closed loop [4]; second, elimination of circulating current in each cell does not always leads to minimization of additional losses. To reduce power losses in the system, special programs can be applied, e.g. the optimal power flow (OPF) program which is optionally offered in the powerful PowerWorld computer program. This approach provides minimization of power losses by adjusting the modes of operation and settings of generating units. To optimize a meshed system, generic algorithms with the goal function of the least power losses could be applied.

\section{FORMULATION OF THE PROBLEM AND THE WAY TO SOLVE IT}

The solution to the problem of power loss minimization in a meshed nonuniform network is sought-for through adjusting its parameters without changing the algorithm of control over generating facilities. For this, the notion of circulating current and the method of its elimination are of importance.

A meshed network can have a number of loads and generating stations, with a slack bus being its necessary component. A network consisting of several cells is shown schematically in Fig. $1 a$ (cells III and IV are singled out in Fig. 1b).
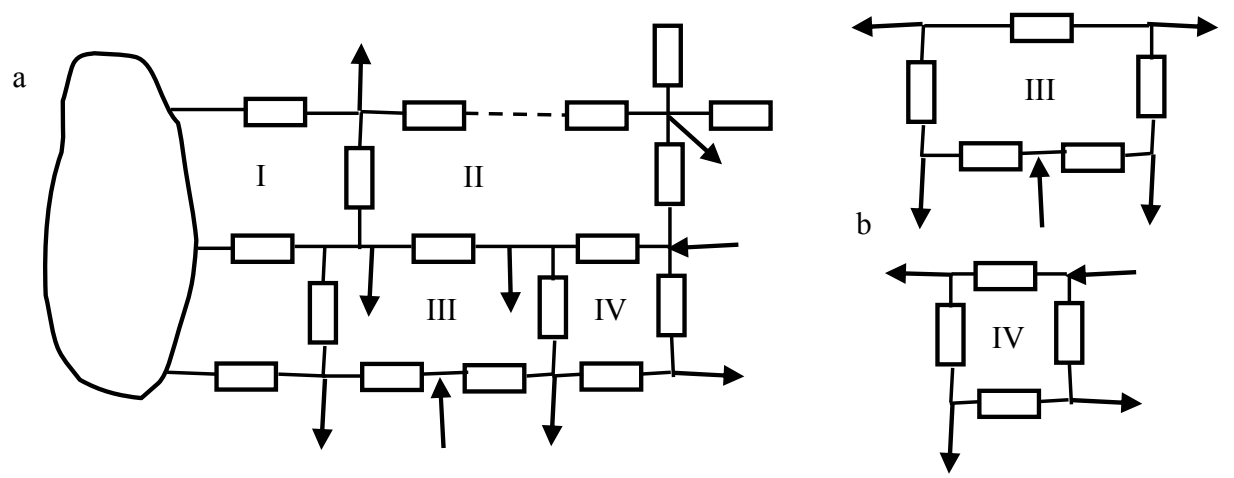

Fig. 1.A meshed network with consumer loads $\longrightarrow$ and infeeds

$a$ - a fragment of the network, $b$ - singled out cells III and IV with equvalent loads and infeeds.

A closed loop (cell) is shown in Fig. 2.

The calculation of loop voltage $\dot{U}_{c i}$ which causes circulating current $\dot{I}_{c i}$ and the related questions are considered in [4]. The main points illustrated by Fig. 2 are as follows:

$$
\begin{aligned}
& \dot{U}_{c i}=j \sum_{k=1}^{n} \dot{I}_{l, k} \sum_{i=k+1}^{n+1} \Delta X_{\Sigma x, i} ; \\
& \dot{I}_{c i}=j \frac{\sum_{k=1}^{n} \dot{I}_{l, k} \sum_{i=k+1}^{n+1} \Delta X_{\Sigma x, i}}{\dot{b}_{u \Sigma x} \sum_{m=1}^{n+1} R_{m}}
\end{aligned}
$$

In designation of current $\dot{I}_{l, k}$ the subscript " $k$ " stands for numbers $1,2,3, \ldots$; the delta reactance $\Delta X_{\Sigma x, i}$ of branch number $i$ is calculated as 


$$
\Delta X_{\Sigma x, i}=X_{i}-R_{i} \operatorname{tg} \alpha_{\Sigma x}
$$

where $X_{i}$ and $R_{i}$ stand for the direct sequence reactance and active resistance of the impedance $\dot{Z}_{i}$ of a power line branch.

In turn, $\operatorname{tg} \alpha_{\Sigma x}$ and factor $\dot{b}_{u \Sigma x}$ are:

$$
\begin{gathered}
\operatorname{tg} \alpha_{\Sigma x}=\frac{\sum_{i=1}^{n+1} X_{i}}{\sum_{i=1}^{n+1} R_{i}} ; \\
\dot{b}_{u \Sigma x}=1+j \operatorname{tg} \alpha_{\Sigma x} .
\end{gathered}
$$

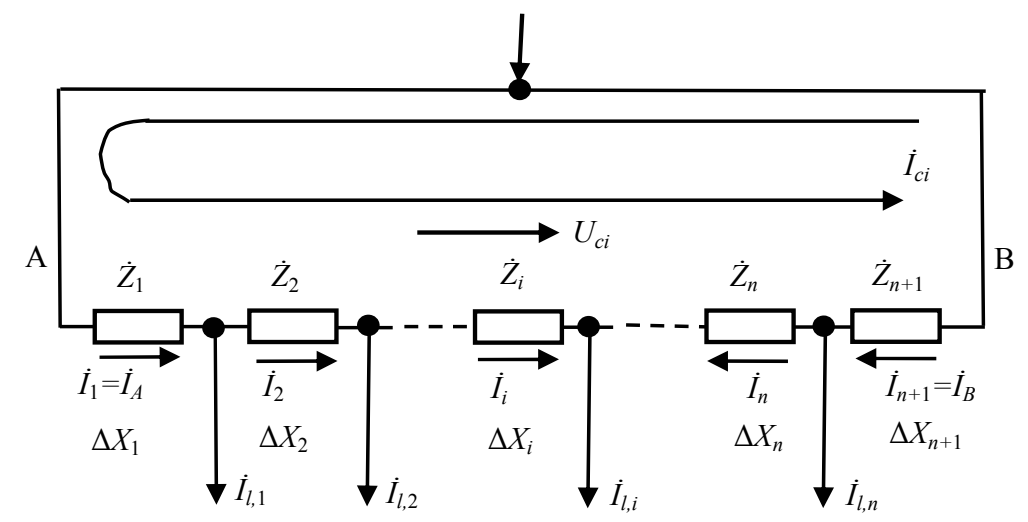

Fig. 2. A closed loop (cell):

$\dot{Z}_{1} \ldots \dot{Z}_{n+1}$ - impedances of loop branches; $\Delta X_{1} \ldots \Delta X_{n+1}$ - delta reactances; $\dot{I}_{l, 1} \ldots \dot{I}_{l, n}-$ load currents; $\dot{I}_{1} \ldots \dot{I}_{n+1}-$ branch currents; $\dot{I}_{c i}, U_{c i}$ - circulating current and corresponding voltage.

The elimination of circulating current is performed by bringing opposing voltage or complementary reactance in the loop [5-7].

Additional power losses resulting from circulating current are determined by the following formula:

$$
P_{c i}=I_{c i}{ }^{2} \sum_{i=1}^{n+1} R_{i}
$$

To eliminate circulating current, it is necessary to bring in the loop opposing voltage $\dot{U}_{o p}=-\dot{U}_{c i}$ or, at the beginning/end of the loop (direction A or B, respectively, in Fig. 2), a compensating reactance determined by the formula:

$$
X_{c}=\operatorname{tg} \alpha_{\Sigma \Delta} \sum_{m=1}^{n+1} R_{m}
$$

where

$$
\operatorname{tg} \alpha_{\Sigma \Delta}=\frac{\sum_{k=1}^{n} \dot{I}_{l, k} \sum_{i=k+1}^{n+1} \Delta X_{i}}{\sum_{k=1}^{n} \dot{I}_{l, k} \sum_{i=k+1}^{n+1} R_{i}} .
$$


At calculation of circulating currents it is assumed that all loads remain constant. A circulating current does not flow into loads, so when it is eliminated the loads do not change; therefore we can separately, in turn, consider all cells in Fig.1 and take measures to eliminate circulating currents there. Based on iterative calculations it is possible to reduce the circulating currents in all cells as close to zero as required.

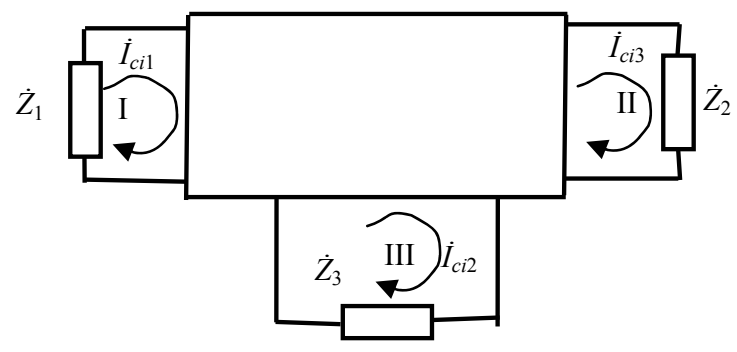

Fig. 3. Interaction between cells in a meshed network

To prove it, consider the equivalent scheme in Fig. 3. Here $\dot{Z}_{1}, \dot{Z}_{2}, \dot{Z}_{3}, \ldots$ are some branch impedances of cells I, II, III,... . Suppose that the circulating currents $\dot{I}_{c i 2}, \dot{I}_{c i 3} \ldots$ in all cells are eliminated except in cell I. After in cell I the opposing voltage $\dot{U}_{o p 1}$ is brought for which power $S_{o p 1}$ is necessary, the circulating currents $\dot{I}_{c i 2}, \dot{I}_{c i 3}, \ldots$ will be induced in the rest of cells, which would require the powers $S_{\text {ind }, 2}, S_{\text {ind }, 3} \ldots$ according to the expressions:

$$
S_{\text {ind }, 2}=\dot{A}_{21} S_{o p 1} ; \quad S_{\text {ind }, 3}=\dot{A}_{31} S_{o p 1} ; \ldots,
$$

where $\dot{A}_{21}, \dot{A}_{31}, \ldots$ are mutual coefficients with the following properties:

$$
\begin{aligned}
& \text { 1) } \dot{A}_{21}=\dot{A}_{12} ; \quad \dot{A}_{31}=\dot{A}_{13}, \\
& \text { 2) } A_{21}<1 ; \quad A_{31}<1 \ldots,
\end{aligned}
$$

because there are power losses on a path from cell I to cell II, cell III, ....

3) $A_{21}+\dot{A}_{31}+\ldots<1$

because cell I can never transmit all its energy to outer circuits without amplifying its signal.

After the circulating current has been eliminated in cell I, such currents appear in cells II, III,... as a result of the signal induced from cell I. Having eliminated those, we induce one more circulating current $\dot{I}_{c i 1}$ in cell I. As shown above, this current will be smaller than that in cell I at the beginning $\left(I_{c i 1}\right)$. The second series of these measures will reduce the circulating current in cell I still more, and so on, until it is reduced to a desired degree. In such a way the circulating currents in all cells of the meshed system can be eliminated.

Based on the above considerations, an algorithm for upgrading a nonuniform meshed network has been developed (see Fig. 4). 


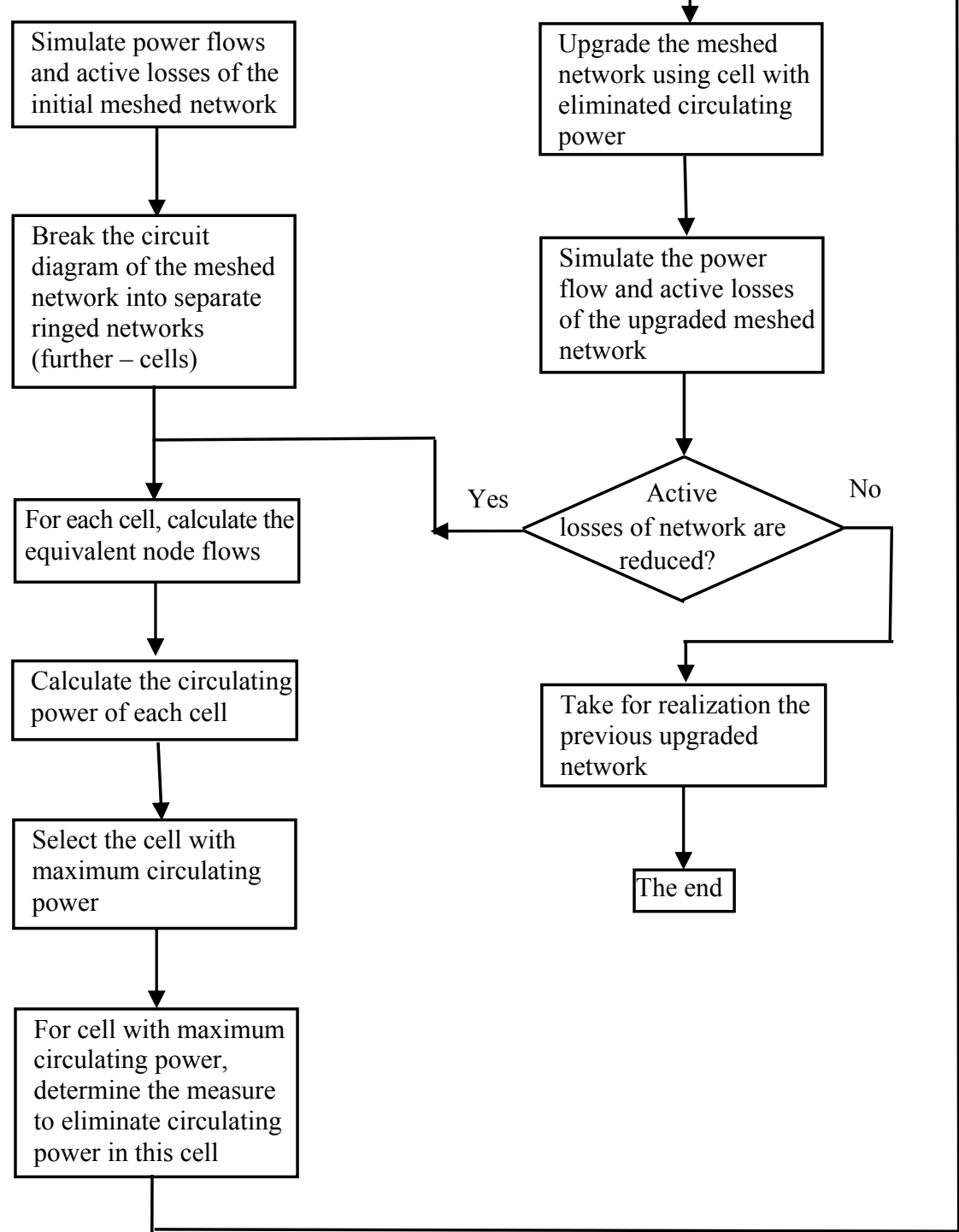

Fig. 4. The algorithm for upgrading a meshed non-uniform network.

\section{VERIFICATION OF THE METHOD BY MODELING AND CALCULATIONS}

To verify the method, testing on a model $110 \mathrm{kV}$ network (circuit diagram in Fig. $5 a$ ) has been performed. In Fig. 5 all phase currents in a three-phase network are shown multiplied by $\sqrt{3}$, since in the above formulas this term disappears. With the assigned branch parameters and loads, the power flows in all branches and the total active power losses of the considered network were determined by the PowerWorld program. After that, cells I, II, III, IV were singled out and their node currents calculated using the external load values shown in Fig. $5 a$ and the branch flows calculated by the mentioned program. As an example, in Fig. $5 b$ cell IV is presented. Using the node currents and branch parameters (resistance $R$ and 


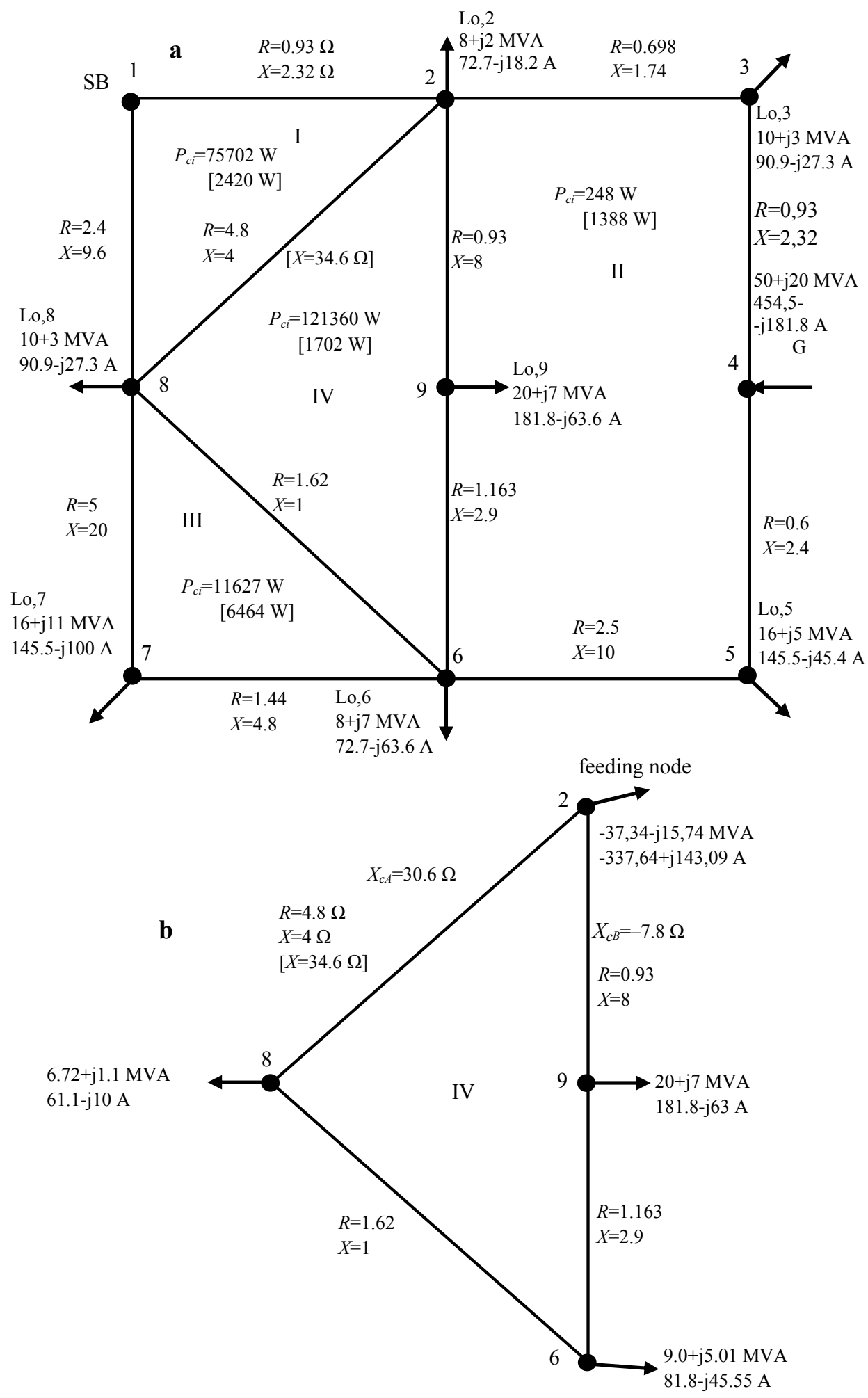

Fig. 5. A model non-uniform network: $a$ - circuit diagram of the network;

$b$ - singled out cell IV with the maximum (for cells I, II, III, IV) circulating power $P_{c i}$; $\mathrm{SB}$ - a slack bus, $\mathrm{G}$ - a power plant. 
reactance $X$ ) of the cell, circulating power $P_{c i}$ and complementary reactance $X_{c}$ from directions $\mathrm{A}$ and $\mathrm{B}$ were determined by formulas (6) and (7) applying the Excel program. The quantities obtained are shown in Fig. $5 a$. As can be seen, cell IV has the greatest circulating power $P_{c i}$ and is therefore upgraded. As a means of upgrading, complementary reactance $X_{c A}=30.6 \Omega$ was used, because it can simply be realized using an induction coil. This reactance is introduced between nodes 2 and 8. The new value of branch reactance is shown in Fig. 5 in square brackets.

The upgraded grid is then subject to simulation by the PowerWorld program, and the above procedure is repeated. The results $\left(P_{c i}\right)$ are shown in Fig. $5 a$ in square brackets. Now, cell III has the maximum circulating power $P_{c i}$ and this cell is to be upgraded. The results of upgrading (reducing network losses) are shown

\begin{tabular}{|c|c|}
\hline $\begin{array}{c}\text { Upgraded } \\
\text { cell }\end{array}$ & $\begin{array}{c}\text { Network } \\
\text { loss, MW }\end{array}$ \\
\hline Initial grid & 3.79 \\
\hline cell IV & 3.05 \\
\hline cell III & 2.95 \\
\hline cell II & 2.97 \\
\hline
\end{tabular}
below. As can be seen, the decrease in the cell circulating power may reduce the network losses only at the first steps. Further measures give no gain. If the upgrading of cells is made all the time by introducing a positive reactance, the reactive power demanded from the feeding nodes grows, which is followed by a growth in the active losses.

The results achieved show that the minimum circulating power of a meshed network's cells can serve as indicator that it is necessary to reduce power losses in this network.

\section{CONCLUSIONS}

1. It is possible to reduce additional losses in a meshed non-uniform network by consecutive elimination of circulating current in the cells of this network.

2. For this purpose, the meshed network should be disintegrated into separate cells, which formally are closed loops with the node equivalent currents.

3. The elimination of cell circulating current ensures the decrease in a network's losses only to some extent.

\section{REFERENCES}

1. Vanags, A. (2007). Elektriskie tīkli un sistēmas, I daļa. Rīga: RTU (Ievads).

2. Schlabach, J., \& Karl-Heinz Rofalski, K.-H. (2007). Power System Engineering. Weinheim: Wiley-VCH Verlag GmbH \& Co. KgaA (Ch.5).

3. Vanags, A. \& Krišāns, Z. (2005). Elektriskie tīkli un sistēmas, II daḷa. Rīga: RTU (6.nodala).

4. Survilo J. (2008). A ringed non-uniform network: how to raise its efficiency. Latv. $J$. Phys. Tech. Sci. (6), 20-32.

5. Холмский, В.Г. (1975). Расчет и оптимизация режимов электрических сетей (специальные вопросы). Москва: Высшая школа (гл. 6).

6. Идельчик, В.И. (1989). Электрические системы и сети. Москва: Энергоатомиздат (гл. 3).

7. Miller, H. \& Malinowski, H. (1993). Power System Operation. San Francisko (California): Mc Graw Hill (Ch. 2). 


\section{SLĒGTO ELEKTRISKO TĪKLU NEHOMOGENITĀTES KOMPENSĀCIJA}

\section{J. Survilo}

Kopsavilkums

Slēgtiem elektriskiem tīkliem ir lielāks elektroapgādes drošums. Turklāt nehomogēniem slēgtiem tīkliem ir lielāki jaudas zudumi nekā homogēniem. Izstrādāti nepieciešamie tehniskie pasākumi, lai tos mazinātu. Tīkla dažos zaros ir nepieciešams ievadìt pretī vērstus eds avotus vai ieslēgt reaktīvo pretestību. Parametru noteikšanai nehomogēnie elektriskie tîkli jāsadala atsevišķās šūnās - cilpveida shēmās ar ekvivalentiem mezglu punktu slodzēm. Katrā no šīm slodzēm ietilpst reālā mezglu punkta slodze un incidentu zaru plūsmas. Pretēji vērsto eds lielumu vai reaktîvo pretestību ievada šūnā ar vislielāko cirkulējošo jaudu. Gadījumā, ja pēc pirmā aprēķinu soḷa tīkla summārie jaudas zudumi pietiekoši nesamazinās, tiek veikts nākamais aprēḳinu solis un uzlabojumam izvēlēta cita šūna. Šūnu uzlabojuma process jāturpina tik ilgi, kamēr tīkla summārie zudumi turpina samazināties.

20.03.2009. 